\title{
The Effect of Group Reading Strategy on Critical Thinking Skills in Thai EFL University Learners
}

\author{
Pasara Namsaeng ID $\square 1$, Dr. Apisak Sukying iD 2 \\ ${ }^{1}$ English Language Department, Faculty of Education, Chaiyaphum Rajabhat University, Chaiyaphum Province, Thailand \\ ${ }^{2}$ Assistant Professor Department of Western Languages and Linguistics, Faculty of Humanities and Social Sciences, \\ Mahasarakham University, Maha Sarakham Province, Thailand \\ $\triangle$ Corresponding Author: Pasara Namsaeng, E-mail: pasaranamsaeng@live.com; pasara.na@cpru.ac.th
}

\section{ARTICLE INFORMATION}

Received: December 17, 2020

Accepted: February 10, 2021

Volume: 3

Issue: 2

DOI: $10.32996 /$ jeltal.2021.3.2.4

\section{KEYWORDS}

Group Reading Strategy, Critical Thinking, collaborative learning, active learning, Thai EFL university learners

\section{ABSTRACT}

Group Reading Strategy (GRS), a collaborative reading activity, offers individual contributions to a shared goal using an active learning approach. This mixed-methods research examined the effect of GRS on the critical thinking skills of Thai EFL university learners and explored learners' perceptions of the GRS process. The critical thinking self-assessment questionnaire, a logbook, and semi-structured interviews were used to collect data. The analysis of the quantitative findings revealed that GRS fostered critical thinking skills in Thai EFL university learners. The results also showed that some intrinsic characteristics of critical thinking skills were cultivated before others. Overall, the current study demonstrated an increase in critical thinking skills through the GRS learning process. The qualitative findings revealed that participants held positive opinions regarding the GRS approach to facilitate active learning environments. Specifically, Thai EFL university participants viewed GRS as peer-assisted learning and a collaborative learning approach, which could, in turn, lessen adverse learning factors. However, some factors, including culture, time-allocation for the GRS process, and types of assessment, also influenced the learning process of GRS activities. Overall, this study indicates that GRS could have an impact on Thai EFL university learners' critical thinking skills, at least to some extent. However, longitudinal studies are still required in future investigations.

\section{Introduction}

Critical thinking is one of the criteria of the Common European Framework of Reference for Languages (CEFR) (Council of Europe, n.d.; Silalahi, 2017) and is a crucial skill that is required by many employers (Changwong, Sukkamart, \& Sisan, 2018) as well as higher education institutions. Therefore, to be able to work and to continue higher education, critical thinking must be fostered in university learners. Several definitions can define critical thinking. First, critical thinking is the process whereby an individual deploys criteria and standards into their thought. Second, critical thinking is the combination of skills and attitudes to solve problems of an individual person. Critical thinking is also the ability to skepticize and reflect when engaging in an activity. Finally, critical thinking has been described as the ability to judge with purpose and self-regulation (Walker, 2003). Taken together, a critical thinker can be defined as "a good thinker, clear, logical, thoughtful, attentive to the facts, open to alternatives" (Facione, 2016).

The critical thinking has been classified into different levels such as remembering, understanding, applying, analyzing, evaluating, and creating (Wilson, 2016). The characteristics of critical thinkers can be observed through the ability to interpret, analyze, evaluate, inference, explain, and self-control thoughtfully, in which the critical thinker usually possess seven main skills according to Bloom et al. (1956) and Facione (2016), including systematic, inquisitive, judicious, truth-seeking, analytical, open-minded, and confident in reasoning.

K C AL-KINDI CENTER $R$ FOR RESEARCH AND $R$ D DEVELOPMENT Your gateway to world-class research

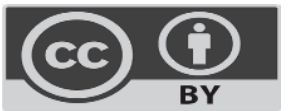

Published by Al-Kindi Center for Research and Development. Copyright (c) the author(s). This open access article is distributed under a Creative Commons Attribution (CC-BY) 4.0 license 
In language acquisition, reading is defined as a process of decoding, understanding, and grasping the message a text (Cline $\&$ King, 2006). During reading, there is a continuous interaction between the reader and the text (Tyson, 2014), which usually stimulates the reader to think when reading intrinsically. Tyson (2014) defined reading as the interaction and involvement of the reader, text, and activities. Reading has also been defined by models such as top-down, bottom-up, and interactive (Ahmadi, Ismail \& Abdullah, 2013; Tyson, 2014). The interactive model emphazises the metacognitive and cognitive reading strategy awareness, which involves higher-order thinking skills through planning, monitoring, clarifying, and evaluating. Three levels of reading comprehension have been identified, including literal, inferential and critical (Khusniah, 2017). For critical thinking, reading comprehension must go beyond the highest level. Individual readers may not be able to reach this level of critical comprehension resulting in an inability to obtain a full understanding of the text. However, reading collaboratively as a group allows the readers to discuss with their friends, clarify a complex issue, scaffold one another, and go beyond the level of critical comprehension, which the individual readers may not have achieved on their own.

Group reading strategy (GRS) is defined as a multicomponent reading strategy used among group members while reading (Vaughn et al., 2011). The GRS provides group members with an opportunity to discuss, brainstorm, and crosscheck a text, thereby scaffolding learners' critical thinking. To illustrate, the GRS comprises six different roles, which include leaders, summarizers, visualizers, questioners, and connectors. Each of the GRS roles is responsible for its own task and contributes to the group reading. As such, learners' critical thinking skills can be fostered through collaborative and interactive discussions. Research on GRSs indicates that group reading helps promote learners' critical thinking skills. For example, spontaneous group discussion supports the psychological activities that foster the learners' synergy through the exchange of opinions, ideas, and views towards the information in the text (e.g., Ay, Karakaya, \& Yilmaz, 2015; Karimi \& Veisi, 2016; Winarso \& Dewi, 2017). In this vein, GRSs can promote deeper insights into reading materials and, therefore, increase a learner's ability to think beyond the text.

Group reading includes several strategies. For example, the Collaborative Strategic Reading or CSR (Zagoto 2016) is a strategy for reading comprehension where practitioners teach various reading strategies before allowing the student to do activities in a group. Similarly, reciprocal reading has been defined as interactive reading, whereby the students are asked to activate their prior knowledge while reading the text (Ahmadi \& Gilakjani, 2012). Both these strategies are the instruction models allowing peers to reciprocally support one another (Cavendish \& Hodnett, 2017). When group reading takes place, several reading strategies will be applied. Initially, the teacher must train students in the reading strategies, and this is followed by the autonomous group reading. Armbruster (2010) suggested seven reading strategies that can be taught to the students, which include the ability to monitor themselves, to paraphrase the reading passages, to organize the idea, to reorganize and retell the story, and to make a summary of the reading text. Another study, by The Ontario Ministry of Education (2005), proposed three stages of group reading. In this first stage, students are preparing to read (e.g., preview the text, analyze the feature, find the organization of the patterns, anticipate the guide of the text, identify the signal word). The second stage is engaging the reading. In this stage, the readers can still ask questions, try to understand the text, make inferences, visualize, make connections, think, and take notes. The last stage of reading is reacting to the reading by thinking about the text, which can lead to critical thinking.

The current study used six reading strategies proposed by Lynch (2018). These strategies include creating a visual, making a connection, questioning, determining importance (indicating the main ideas), inferring, synthesizing, and noticing the author's craft (critical thinking skill). The strategies are linked to six roles in the GRS: leader, summarizer, visualizer, questioner, clarifier, and connector. The leader helps generate self-regulation skills, the summarizer helps foster interpretation and explanation skills and the visualizer helps in seeing things systematically. Next, the questioner supports inquisitive skills, while the clarifier strengthens truth-seeking skills. Finally, the connector emphasizes referencing skills by connecting relevant information together. Specifically, in the current study, the student in the leader's role will be the timekeeper for the group as well as present or share the discussed ideas to the whole class. The summarizer's role is to outline the main ideas of the reading, which can be done paragraph by paragraph or for the whole passage depending on the participant's preferences and timeframe. The visualizers should draw a picture or create a mind-map for the reading passage. The questioners will ask questions related to the passages, meaning that they need to identify unclear points in the passage. The clarifiers should answer these questions. Finally, the connectors will relate the reading passages to the world, to the country, to their own setting, and themselves. The group members can assist each other in their roles. For example, the participant who takes a summarizer's role can help clarifiers by answering the questions, but the students were asked to perform their own roles to the best of their ability before asking for help from the other group member.

Critical thinking can be cultivated through the use of GRS in EFL classrooms in both L1 and EFL contexts. In the US, Hove (2011) studied the development of critical thinking skills in the high school English classroom. The critical thinking strategy instruction 
was used, and critical thinking strategies were taught explicitly. The instructional activity was used for only the experimental group in the small group discussion, whereas the control group used traditional teaching without small group discussions. The students in the experimental group were scaffolded to think about the concept, compare to previous knowledge, consider the alternatives, and synthesize the information. Hove also used the "think aloud" model, which allowed the students to complete the task by themselves, and employed the technology-supported material or SmartBoard in the small group discussion. The results indicated that students who received the treatment were better at applying their critical thinking skills compared to the control group, as illustrated by the assessment scores after the instruction. Similarly, Boardman et al. (2016) studied the efficacy of collaborative strategic reading (CSR) in middle school students. During the CSR session, three strategies were used: preview, click and clunk, and wrap-up. The findings revealed that the teacher-rated work was deemed to be higher quality when students were taught with CSR, and students provided more positive feedback when taught with this method. Overall, CSR improved students' reading comprehension, especially for complicated reading passages.

In the EFL context, several scholars form Iran and China found that critical thinking did not correlate with the level of language proficiency; however, critical thinking has a positive effect on the learner's reading comprehension (Barjesteh \& Vaseghi, 2012; Wang \& Seepho, 2017). Critical thinking can be fostered through group discussion by helping to organize ideas, clarify complex issues, and think independently. Moreover, critical thinking can be promoted by writing a report after reading by encouraging the learners to use their imagination, to make a decision, and to engage in higher-order thinking, which should lead them to be critical and creative. Indeed, several studies in EFL contexts have shown that critical reading activities promoted "truth-seeking, open-mindedness, systematicity, inquisitiveness, self-confidence, and maturity" (Bedir, 2013; Fahim \& Sa'eepour, 2011; Karimi \& Veisi, 2016; Tung \& Chang, 2009; Zoghi, Mustapha, \& Maasum, 2010).

Research studies on group reading and critical thinking in a Thai context are still rare and inadequate. Thai learners lack reading strategies resulting in inadequate reading comprehension (Akkakoson \& Setobol, 2009). Moreover, Thai students' critical thinking skills are low. In 2018, the Analytical and Critical Reading Test was conducted in over six thousand students in 12 private universities in Thailand. The average score was about six (out of 15), which is considered to be a low level of critical thinking skills (Ploysangwal, 2018). There is thus an urgent need to promote critical thinking skills in these students, and this could be achieved via group reading. One study compared the effect of the traditional teaching method and reciprocal teaching and found that students' reading comprehension in the reciprocal teaching group was better than their traditionally-taught peers (Yoosabai, 2008). The findings also showed that the reciprocal teaching method improved students' metacognitive awareness. However, in this study, only comprehension was measured, not critical thinking abilities. Thus, the effect of this approach on critical thinking skills, particularly the role of the influencer, remains to be determined. Another study showed that high school learners developed their critical thinking after being trained in a new learning management strategy called the "PUCSC" model (Changwong et al., 2018). However, it is not clear whether a greater benefit could be achieved by using this model in small groups.

Similarly, Kasemsap and Lee (2015) studied the application of different strategies during the reading of English texts in a Thai vocational college. Using surveys, think-aloud strategies, and semi-structured interviews, the authors revealed that the use of reading strategies was similar in both high and low English proficiency students; however, the high English proficiency group used more reading strategies than the low English proficiency group. Interestingly, the skilled and unskilled readers did not perceive the reading strategies equally. The results also showed that the reading strategies used were not adequate or sufficient to promote critical thinking. Finally, a study on second language reading in Thai EFL university contexts indicated that reading strategies based on a collaborative learning approach in an English class improved students' confidence and reading comprehension rather than improving their critical thinking (Suwantharathip, 2015). Their findings also showed that explicit reading instruction enhanced informational text comprehension and reading engagement. However, comparatively little is known about students' critical thinking through the use of collaborative reading or GRS.

Overall, these studies, which have been conducted over the globe, indicate that students significantly increased their critical thinking skills after being trained in GRS. However, relatively little is known about the effect of GRS in facilitating Thai EFL university learners' critical thinking. Indeed, previous research has focused solely on either reading comprehension or critical thinking, but the two concepts have not been studied together. Thus, there is still a need for additional investigation into the roles of GRS in facilitating critical thinking in Thai EFL university students. The purpose of the study is to examine the influence of the group reading strategy of Thai EFL university learners on critical thinking. The current study also aims to explore learners' perceptions of the group reading strategy on critical thinking. In response to the research objectives, two research questions are formulated:

1. Does the group reading strategy facilitate Thai EFL university learners' critical thinking? 


\section{What are Thai EFL university learners' perceptions of group reading strategies?}

\section{Method}

A quasi-experimental research design was used to test the effect of the group reading strategy (the treatment) on critical thinking skills (White \& Sabarwal, 2014), using a single group, pretest-posttest design. For the quantitative data collection, the participants were administered the critical thinking self-assessment questionnaire before and after the treatment. The qualitative data was collected during and after the treatment. The participants were required to reflect on their perceptions about the group reading strategy through logbook writing every fortnight and the semi-structured interview after the treatment.

\subsection{Participants and setting}

The participants were 61 English major students from one Thai EFL university, aged between 18-22 years old, and enrolled in the compulsory English reading course. As English majors, all participants were familiar with English language teaching and learning. The convenience sampling technique was used due to the limitation in the number of participants. The participants were considered a homogenous group as their learning natures, characteristics, and language competencies were similar. The reading instruction in the classroom was encouraged by the teacher. That is, students were taught with grammar-translation and teacher-fronted methods in their other university classes, but the current study focused more on communication as well as student-centred learning.

\subsection{Instruments}

This current study used a mixed-methods research design. There were three research instruments. The critical thinking selfassessment questionnaire was used to collect the quantitative data before and after the GRS treatment. The logbook and the semi-structured interview were used to collect the qualitative data.
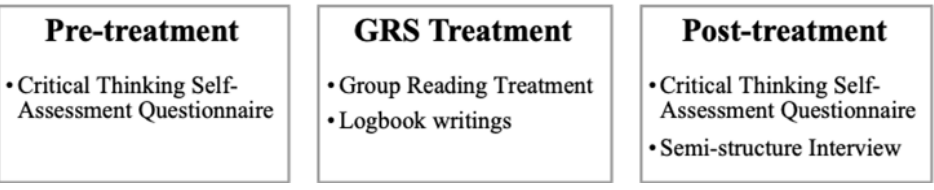

Figure 1: Research instruments used in before, during, and after GRS

\section{The critical thinking self-assessment questionnaire}

The Critical Thinking Self-Assessment Questionnaire items were created by combining the frameworks of Facione (2016) and Bloom et al. (1956). The framework consists of seven sub-skills of critical thinking: systematic, judicious, analytical, confident, open-minded, truth-seeking, and inquisitive. There were 35 items and participants were asked to rate their level of critical thinking by using Likert rating score from 1 to 5 ( $5=$ very high, $4=$ high, $3=$ medium, $2=$ low, and $1=$ very low).

\section{Logbook}

The GRS treatment covered six weeks but the participants were only required to write in their logbook once a fortnight (i.e., three entries in total). The participants were asked to cover six aspects in each of their logbook entries: the title of the passage, the assigned role(s), what they gain from GRS, if (and how) GRS helped to develop their critical thinking, how the assigned roles contribute and support group reading, and other comments or suggestions. The logbook was written both in Thai and English because the learners' L2 proficiency was limited.

\section{Semi-structured interview}

After the GRS, ten participants were randomly selected for the semi-structured interview. Each interview session lasted approximately 20 minutes with voice recording. The scope of the interview included critical thinking and the group reading strategy. The semi-structured interview was used to recall the overall understanding and perception of the participants after GRS and to triangulate the data collected through the questionnaire and logbook. During the interview, the participants could express their ideas and feelings, which can construct new insights that were not found in the questionnaire or logbook sessions. In addition, by using their mother tongue, language burdens were minimized.

\subsection{Data collection procedures Research instrument validity}

The validity of all three research instruments was verified using the Index of Item-Objective Congruence (IOC). Seven experts validated the questionnaire, logbook and the questions of the semi-structured interview. Each expert had at least ten years of working experience in English Language teaching at the university's level. The score range of IOC is from -1 to +1 ( -1 means 
Incongruent, 0 means Questionable, and +1 means Congruent). The IOC average score for the questionnaire is 0.71 , which is valid. There were four items that were under 0.5 and revised according to the experts' suggestions. The logbook and interview questions were rated 0.93 and 0.86 , respectively. None of the items in the logbook or interview questions were rated below 0.5 , meaning that all items were valid.

\section{Reading material selection}

Six reading passages and one preparatory passage were used in GRS. All reading passages were adopted from "More Reading Power 3" published in 2012 (British Council, n.d. ; Exam English, n.d.) and were chosen according to three criteria. First, passages were selected at the B2 level as this is likely to be the level for English major university students. Second, the reading passages must contain up-to-date information, which can foster the readers to be able to critically solve new problems arising from the modern world (Hafni, 2017). As such, reading passages that relate to the world's current issues were selected. Finally, the readers' preferences and interests must be taken into consideration. If students can relate the reading materials to their personal experiences this leads to better engagement in the group reading strategy. Based on these criteria, the following reading passages were selected: Are zoos a good thing?, An Oceanful of Plastic, Food for the 21st Century: Insects, Work-life balance, Study problems - help is here, Are celebrities bad for you?, and Job adverts.

\section{Group reading strategy}

Before the experiment, the learners were required to complete the critical thinking self-assessment questionnaire. The GRS was presented to the students by the teacher until it was fully understood. The preparatory passage was then read to students. Participants were required to perform the GRS for six weeks and to reflect on their perceptions about the GRS through logbook writing every fortnight. The GRS treatment lasted 1.5 hours per class. Each class involved six steps, including introduction, preparation for GRS, GRS, preparation for group sharing, group sharing, and wrap-up. One reading passage was provided for each week. There were six reading passages in total. After the 6-week GRS, the critical thinking self-assessment questionnaire was distributed to the students again. Also, ten participants, who were randomly selected as representatives, were given the semi-structured interview with voice recording. Then, the voice recording was transcribed for content analysis.

\subsection{Data analysis}

The data from the student's critical thinking self-assessment in the form of the five-point Likert rating scale was calculated as a percentage, mean and standard deviation (S.D.). The Statistical Package for the Social Sciences (SPSS) was then used to analyze the data. The data from the logbook and interview were analyzed by content analysis. Intercoder reliability was used to avoid bias coding (Campbell, Quincy, Osserman, \& Pedersen, 2013). Then, an experienced intercoder verified the data. The themes of skills were aligned with the seven characteristics of the critical thinking self-assessment questionnaire, and the themes of perceptions were based on the qualitative data. Pseudonyms were used to conceal the participants' identities.

\section{Results}

\subsection{Thai EFL university learners' critical thinking skills}

In response to Research Question 1, the quantitative data obtained from the pre- and - post critical thinking self-assessment questionnaires were analyzed using SPSS software. The results from the pre-and post-treatment questionnaires were also compared to determine whether the GRS intervention affected critical thinking skills in Thai EFL university participants. Table 1 shows the results of these questionnaires.

Table 1: Critical thinking skills in Thai EFL university participants

\begin{tabular}{|c|c|c|c|c|c|c|c|c|}
\hline \multirow[t]{2}{*}{ CT aspects } & \multicolumn{2}{|c|}{$\begin{array}{l}\text { Pre-CT } \\
\text { self-assessment }\end{array}$} & \multicolumn{2}{|c|}{$\begin{array}{l}\text { Post-CT } \\
\text { self-assessment }\end{array}$} & \multirow[t]{2}{*}{ S.D. } & \multirow{2}{*}{$\begin{array}{l}\text { Difference } \\
(\%)\end{array}$} & \multirow[t]{2}{*}{$t$-value } & \multirow[t]{2}{*}{$p$-value } \\
\hline & Score & $\%$ & Score & $\%$ & & & & \\
\hline Confident & 3.50 & 70 & 3.72 & 75 & 0.72 & 5 & 3.214 & $p<.032$ \\
\hline Systematic & 3.40 & 68 & 3.62 & 72.4 & 0.77 & 4.4 & 7.701 & $p<.002$ \\
\hline Truth-seeking & 3.73 & 74.6 & 3.92 & 78.4 & 0.74 & 3.8 & 5.033 & $p<.007$ \\
\hline Analytical & 3.64 & 72.8 & 3.77 & 75.4 & 0.90 & 2.6 & 1.689 & $p<.167$ \\
\hline Inquisitive & 3.88 & 77.6 & 4.00 & 80 & 0.88 & 2.4 & 2.146 & $p<.098$ \\
\hline Judicious & 3.82 & 76.4 & 3.90 & 78 & 0.76 & 1.6 & 1.430 & $p<.226$ \\
\hline Open-minded & 4.00 & 80 & 4.02 & 80.4 & 0.77 & 0.4 & 0.341 & $p<.750$ \\
\hline Overall & 3.71 & 74.2 & 3.85 & 77 & 0.79 & 2.8 & 2.839 & 0.004 \\
\hline
\end{tabular}

The findings from the questionnaire show that Thai EFL university participants had an intermediate to high level of critical thinking skills. More specifically, the current results showed that overall critical thinking skills were increased by $2.8 \%$ following 
the GRS. The three most highly developed aspects were confident, systematic, and truth-seeking sub-skills, which increased by $5 \%, 4.4 \%$, and $3.8 \%$, respectively. These aspects of critical thinking also showed a significant improvement between pre-andpost- questionnaire scores. Although there was also an increase in analytical (2.6\%), inquisitive (2.4\%), judicious (1.6\%), and openminded $(0.4 \%)$, the statistical analysis revealed no significant differences between pre-and-post questionnaire scores. Overall, these results show that Thai EFL university participants' overall critical thinking skills were significantly fostered and suggest that the GRS may have an impact on Thai EFL university participants' critical thinking skills.

The qualitative data from the logbook writing and semi-structured interviews also show critical thinking development in Thai EFL university participants. The themes of skills were aligned with the seven characteristics of the critical thinking self-assessment questionnaire. Table 2 illustrates selected logbook and interview excerpts for each of these characteristics.

Table 2: Aspects of critical thinking in Thai EFL university participants

\begin{tabular}{ll}
\hline Aspects of CT & Logbook writings (Writers) \& Interview Excerpts (Interviewees) \\
Systematic & $\begin{array}{l}\text { GRS helps me develop my CT a bit at a time by looking through the structure of the story, for example, title, } \\
\text { introduction, main idea, cause and effect, and conclusion. (Ann) } \\
\text { It makes me learn how to allocate and share duties equally within the group. (Mil) }\end{array}$ \\
\hline Judicious & $\begin{array}{l}\text { Not only in reading, I think GRS encourages me to practice my communication skills by choosing the appropriate words, } \\
\text { and concise sentences to talk with other group members. (Vivy) } \\
\text { We made a mistake about the step of GRS, so we need to be more deliberate about GRS procedures. (Pae) }\end{array}$ \\
\hline Analytical & $\begin{array}{l}\text { I received various ideas from group members and can analyze them based on different points of view. (Wirun) } \\
\text { When receiving many ideas from the group, we gain more meaningful information to analyze and synthesize. (Prea) }\end{array}$ \\
\hline Confident & $\begin{array}{l}\text { It makes me confident to share my ideas and ask questions methodically. (Susi) } \\
\text { It helps me think outside the box and makes me dare to speak with others. (View) } \\
\text { I was not an outstanding person, but GRS urged me to speak more often. (Irin) }\end{array}$ \\
\hline Open-minded & I got new perspectives from other roles. Sometimes, you need new perspectives to make you open-minded. (Udom) \\
Inquisitive & I listened to and accepted the group members ideas more than before. (Nuni) \\
GRS made me curious and makes me like to ask questions. (Aor)
\end{tabular}

\subsection{Thai EFL university learners' perceptions of GRS}

The second purpose of the study was to explore participants' perceptions of the GRS for developing critical thinking skills. The logbook entries and the ten transcriptions of the semi-structured interview were collected from the participants during and after GRS, respectively. The content was transcribed and then translated into English and verified by an expert and a native speaker. The logbook and semi-structured interview data were coded and verified through several readings to develop theoretical themes and aspects. Table 3 shows Thai EFL university participants' perceptions of the GRS.

Table 3: Thai EFL university participants' perceptions of GRS

Participants' perceptions Logbook writings (Writers) \& Interview Excerpts (Interviewees)

Collaborative learning I learned how to work with other people, and I gained more understanding from my friends' explanations, especially in the parts that I did not fully understand. (Fang)

GRS makes me knowledgeable and gains more understanding of the passage. We can synthesize the data more than before, especially when knowing more from friends. (Prea)

It makes me learn how to manage and share duties equally within the group. I also learn how to ask specific questions from general information. (Nuni)

Active learning I am more creative and active. It is challenging to make it better with a limited time frame. We need to help one another to survive. (Prang)

The way we talk after reading helps us to use our brains to synthesize the information. It makes me take responsibility and wary about what I was reading. (Nidnoy)

My group was very active because we finished everything before the allocated time. The given time was about 15 mins, but we finished it within 10 mins. (Irin)

Overall, the results indicated that the GRS encouraged group members to work collaboratively and participants could exchange their perspectives with other members and learn from others. This suggests that GRS supported collaborative learning environments. The current findings also showed that GRS engaged Thai university participants to read dynamically and effectively. That is, GRS encouraged participants to ask questions and seek responses. Indeed, the GRS emphasizes active learning environments and provide support to student-centred contexts. 


\section{Discussion}

\subsection{Influence of GRS in Thai EFL university learners' critical thinking after GRS}

The current study showed that the Thai EFL university participants' critical thinking skills increased after being trained using the GRS. Both the quantitative and qualitative analyses revealed that the GRS enhances Thai EFL university participants' critical thinking. More precisely, GRS facilitates Thai EFL university participants developing some aspects of critical thinking more effectively than others, including a significant increase in confident, systematic, and truth-seeking skills.

The critical thinking skills in Thai EFL university participants increased because of the intrinsic mechanisms of the GRS process, including preparation, reading engagement, and reaction. For example, the first phase of the GRS technique requires the participants to read alone as a preparatory phase, where learners had the opportunity to preview the structure of the reading text, identify the signal word, and understand the undeveloped idea of the reading passage. During this phase, the systematic skill had been developed. Also, during the preparatory phase, the connector must identify the relevant information to link with the reading passages, which cultivates their inquisitive skills. Participants also need to crosscheck the information, which generates analytical skills.

The peer-mediated learning aspect of the GRS also helps Thai EFL university participants to increase their critical thinking skills. As a task-based learning approach, participants are required to problem solve. Moreover, in a small group of participants, individuals actively distribute ideas, experiences, and perspectives into the group. Participants dynamically work in a team and collaborate in order to complete the tasks. When receiving new ideas, participants need to verify the information, which promotes truth-seeking and judicious skills. Overall, the current findings are consistent with previous studies showing that group reading strategies have a positive effect on learners' critical thinking skills (Hove, 2011; Boardman et al., 2016; Barjesteh \& Vaseghi, 2012; Wang \& Seepho, 2017; Tung \& Chang, 2009; Bedir, 2013).

Critical thinking skills could also be cultivated through the GRS method because of the learning process. Indeed, GRS emphasizes participant activities and participant engagement in the learning process, which promotes active learning. Specifically, this instructional method includes many activities or tasks, such as collaborative reading, brainstorming, concept mapping, simulation, peer tutoring, and problem-based solving. As such, these GRS activities require participants to use critical thinking skills, such as analysis, synthesis, and evaluation. This finding is in line with the previous research that GRS methods require learners to use higher-order thinking skills (Phakiti \& Plonsky, 2018).

The analysis of the qualitative findings also provided further evidence that GRS fosters Thai EFL university participants' critical thinking, especially in confident, systematic and truth-seeking skills. The following excerpts support this claim:

"It makes me confident to share my ideas and ask questions methodically." (Susi)

"GRS helps me think methodically and helps me arrange the priority of the tasks." (Manee)

"GRS makes me pay more attention to the details so that I can analyze and explain to other group members." (Yooyee)

However, although GRS helped promote Thai EFL university participants' critical thinking skills, the statistical analysis revealed no significant increase in some characteristics of critical thinking skills, including open-minded, inquisitive, judicious, and analytical skills. This may be explained by the duration of the study. Such a limited time may not have allowed the participants to have sufficient exposure to GRS techniques.

\subsection{Thai EFL university learners' perceptions of GRS toward critical thinking}

The participants held numerous views of GRS in promoting critical thinking skills. First, GRS was believed to reduce stress, anxiety, and depression. These factors are all considered adverse effects for learning (American College Health Association, 2016). Collaborative learning, therefore, helped lessen adverse learning factors and foster the interaction among the group members allowing them to express ideas without anxiety. The qualitative result also showed that the learners perceived GRS as collaborative learning, had better comprehension while working in a group, and perceived that GRS allowed each group member's idea to be supported. This is illustrated in the logbook excerpt below:

I know how to work with other people, and I gained more understanding from my friend's explanation, especially in the part that I did not fully understand. The group members shared experiences, and I think the process of GRS is good. (Fang)

GRS also supports the learning environment and motivation, which are salient components for successful learning (Nugroho, A., Rizal Akbar Zamzami, M., Ukhrowiyah, 2020; Auster \& Wylie, 2006). The learning environment can aide participants' involvement 
and create an appropriate learning atmosphere, which positively promotes critical thinking skills and disposition (Cheng \& Wan, 2017).

Thai EFL university participants also perceived GRS as an active learning approach. This is perhaps because the participants acquire information and knowledge from their peers rather than the teachers. While working in a group, many ideas arose from different perspectives and this allowed participants to actively acquire new knowledge and ideas. As such, group members become active, actively share and contribute their ideas into a group. This is illustrated in the following logbook excerpt:

GRS makes all group members actively share their ideas, I actively contributed a lot during GRS, such as reading, questioning, and answering, and it made me not lazy to read. (Prang)

Moreover, cultural influences may also play an essential role in participants' perceptions. A previous study found that Thai people are likely to be collectivist and identify other people as in-group or out-group (Thovuttikul, Ohmoto, \& Nishida, 2019). Thus, whenever they feel alone or individuated, they tend to keep quiet, leading to scepticism. By contrast, Thai people feel more relaxed in group situations as it is viewed as a social activity. The following qualitative result supports this claim:

It makes me confident to share my ideas and ask questions methodically. (Susi)

Time-allocation in each step of GRS may also influence participants' perceptions; that is, each role was allocated a limited time. Previous studies showed that participants practicing group learning seemed to be more efficient in time management while learning (B. S. Bloom, 1974). Within the limited timeframe, GRS encourages participants to spend time effectively by prioritizing the importance of the assigned task. Thus, participants perceived themselves to be more systematic, as illustrated in the following logbook excerpt:

GRS helps me think methodically and helps me arrange the priority of the tasks. (Manee)

Moreover, the types of assessment associated with the GRS may also influence the participants' perceptions. During the GRS, participants were required to write the logbook. The logbook is a formative assessment that helps participants review and monitor their critical thinking skills and perceptions. By reviewing the reading passages and strategies, participants may be more judicious (Grosas, Raju, Schuett, Chuck, \& Millar, 2016), as demonstrated in the following logbook statement:

GRS makes me wiser by carefully selecting the reasons to back up my argument. (Kai)

However, the current findings indicated that a smaller number of group members might be more effective. Reducing the numbers of group members may offer a larger space for individual responsibility and allow individual learners to more clearly contribute to the shared goal. Such a concept leads to a revision of the previous model of GRS, as shown in Figure 2.
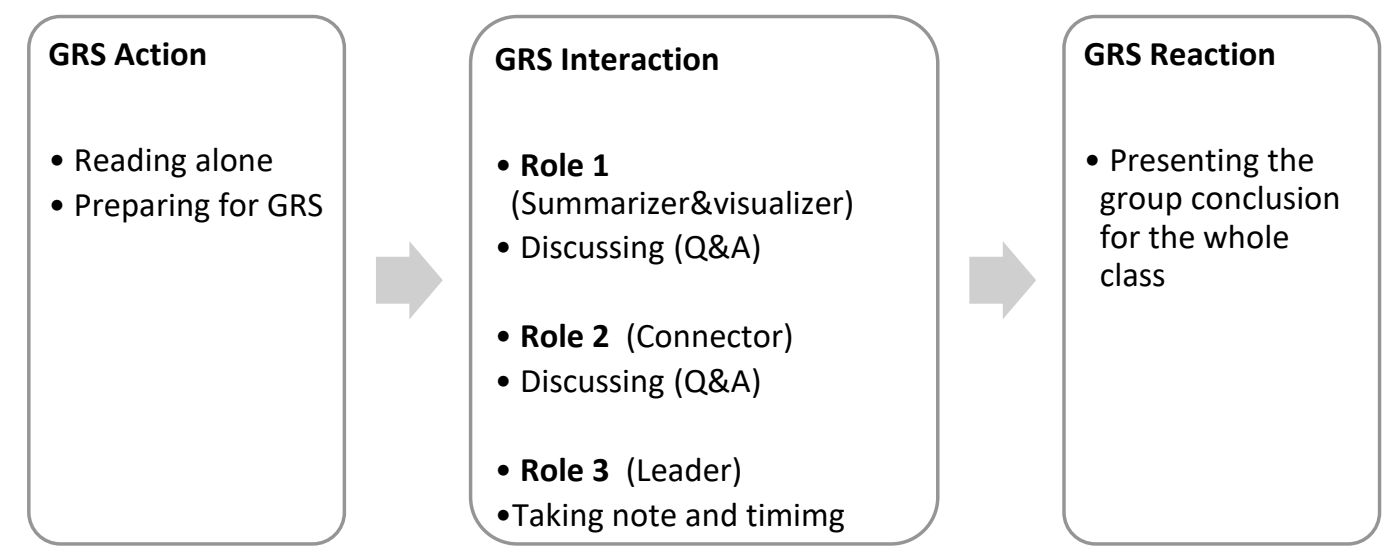

Figure 2: The new model of Group Reading Strategy

Figure 2 illustrates a new model of GRS. This model includes three phases (GRS action, GRS interaction, and GRS reaction) and has only three group members sharing the six original reading strategies. The first phase, GRS action, is the preparatory stage during which the learners are required to read individually and prepare for their role. For example, after finishing reading alone, the connector is required to identify the link between the reading passage and other relevant information. The GRS interaction phase requires individual contributions from each role to a shared goal. Then, all group members collaboratively help to question and clarify the issues. The leader allocates time for all roles and takes notes. Finally, during the GRS reaction phase, the 
leader presents the conclusions of the group to the whole class. Note that the time allocated for each phase depends on the level of the learner's reading proficiency and the length of the reading passage.

To conclude, the quantitative and qualitative findings of the present study showed that GRS nurtured critical thinking skills in Thai university participants. More precisely, the quantitative findings showed significant improvement in critical thinking ability after being trained in group-reading strategies. The qualitative results also provided evidence to support the notion that GRS is a student-centred learning model. Indeed, the GRS allows participants to apply reading tasks to reading materials as well as take ownership of their learning and collaborate, which increases learning engagement, confidence, and judgment. However, some participants expected a smaller number of members in each reading task.

In general, Thai EFL university participants perceived the GRS as a collaborative and active learning process. Collaborative learning helps reduce the participants' stress, anxiety, and depression during reading, which helps maximize their learning outcomes and foster critical thinking via interactions among group members. The positive learning environment, and motivation, also allow the participants to actively acquire innovative ideas and, thus, critical thinking skills. Moreover, the influence of culture, time-allocated of each step, and type of assessment can also influence participants' perceptions.

\section{Conclusion}

The current study examined the effect of a group reading strategy on critical thinking in Thai EFL university learners and explored learners' perceptions of the group reading strategy in promoting critical thinking. The quantitative findings indicated that GRS could enhance Thai EFL university's overall critical thinking, especially for confident, systematic, and truth-seeking characteristics. Indeed, some characteristics of critical thinking skills are cultivated before others, depending on the context. Overall, the intrinsic mechanisms of the GRS process, which include peer-assisted learning and collaborative learning approaches, are likely to positively influence Thai EFL university participants' critical thinking.

The qualitative analysis also revealed a beneficial influence of the GRS method on Thai EFL university participants' critical thinking skills. More precisely, the content analysis indicated that Thai EFL university participants perceived GRS as peer-assisted and collaborative learning approaches, which can decrease adverse learning factors and, therefore, nurturing learning outcomes and critical thinking skills. The learning environment and motivation can also influence participants' critical thinking skills. Additional influences include culture, time-allocated for the GRS process, and types of assessment. To conclude, GRS helps enhance critical thinking skills and develops an active learning approach for Thai EFL university learners.

\section{Limitation and suggestions for future studies}

The current study comprises some limitations. First, GRS may be challenging to administer due to a large number of learners in one class. The researcher cannot closely monitor all learners. Additionally, the inconsistency of the two-week mid-term examination break during GRS may significantly affect the result. Such restrictions may lead to the insignificant findings of some components of critical thinking skills in the current study. The participant sample size in this study is also small, and the GRS training lasted only six weeks, which might be inadequate for the learners to master the reading strategies. Thus, the result cannot be generalized for all Thai EFL learners. Moreover, the current study may observe their learners' critical thinking from reading skills. However, to observe the learners' critical thinking from other skills (e.g., listening, speaking, and writing) may provide different outcomes.

Action research is still a need to investigate GRS in promoting CT because it can design GRS according to the learners' feedback in the second and the third cycles accordingly. The reading skills and speeds must be assessed before GRS. Therefore, it is assured the unison of the participants. Further studies also need to ensure learners' collaboration and discussion during GRS because they may easily fall to the traditionally individual reading rather than group reading. The term "GRS" may block the participants' idea; hence, the simpler term may be employed. Indeed, two-group experimental designs and longitudinal studies should be taken into considerations for future investigations.

Funding: This research received no external funding

Acknowledgments: This study is part of my thesis, and it could not be completed without support from these people. First, I would like to express my deepest appreciation to Assistant Professor Dr Apisak Sukying, my supervisor. He was very supportive, and his comments and advice helped me complete research faster. Second, I would like to thank my classmates in Master of Education in English Language Teaching program, the Faculty of Humanities and Social Sciences, Mahasarakham University, for their cheerfulness and encouragement. Finally, I would like to express my gratitude to my beloved family members, who always support during my hardest time. 
Conflicts of Interest: The authors declare no conflict of interest.

\section{References}

[1] Ahmadi, M. R., Ismail, H. N., \& Abdullah, M. K. K. (2013). The Importance of Metacognitive Reading Strategy Awareness in Reading Comprehension. English Language Teaching, 6(10), 235-244.

[2] Ahmadi, M. R., \& Gilakjani, A. P. (2012). Reciprocal Teaching Strategies and Their Impacts on English Reading Comprehension. Theory \& Practice in Language Studies, 2(10).

[3] Akkakoson, S., \& Setobol, B. (2009). Thai EFL students' use of strategies in reading English texts. The Journal of KMUTNB, 19(3), 329-342.

[4] Anderson, L. W., \& Krathwohl, D. R. (2001). A revision of Bloom's taxonomy of educational objectives. A Taxonomy for Learning, Teaching and Assessing. Longman, New York.

[5] American College Health Association. (2016). American College Health Association-National College Health Assessment II: Canadian Reference Group Executive Summary Spring 2016. In American College Health Association.

[6] Armbruster, B. B. (2010). Put reading first: The research building blocks for teaching children to read: Kindergarten through grade 3. Diane Publishing.

[7] Auster, E. R., \& Wylie, K. K. (2006). Creating active learning in the classroom: A systematic approach. Journal of management education, 30(2), 333-353.

[8] Ay, F. A., Karakaya, A., \& Yilmaz, K. (2015). Relations between self-leadership and critical thinking skills. Procedia-social and Behavioral sciences, 207, 29-41.

[9] Barjesteh, H., \& Vaseghi, R. (2012). Critical thinking: A reading strategy in developing English reading comprehension performance. Journal of Foreign Language Teaching and Translation Studies, 1(2), 21-34.

[10] Bedir, H. (2013). Reading and critical thinking skills in ELT classes of Turkish students. World Applied Sciences Journal, 21 (10), $1436-1439$.

[11] Bloom, B. S. (1974). Time and learning. American psychologist, 29(9), 682.

[12] Bloom, B.S. (Ed.), Engelhart, M.D., Furst, E.J., Hill, W.H., \& Krathwohl, D.R. (1956). Taxonomy of educational objectives: The classification of educational goals. Handbook 1: Cognitive domain. New York: David McKay.

[13] Boardman, A. G., Vaughn, S., Buckley, P., Reutebuch, C., Roberts, G., \& Klingner, J. (2016). Collaborative strategic reading for students with learning disabilities in upper elementary classrooms. Exceptional Children, 82(4), 409-427.

[14] British Council. (n.d.). Upper intermediate B2: choose a reading lesson. Retrieved from https://learnenglish.britishcouncil.org/skills/reading/upper-intermediate-b2

[15] Butler, H. A. (2012). Halpern Critical Thinking Assessment predicts real-world outcomes of critical thinking. Applied Cognitive Psychology, 26(5), 721-729.

[16] Campbell, J. L., Quincy, C., Osserman, J., \& Pedersen, O. K. (2013). Coding in-depth semistructured interviews: Problems of unitization and intercoder reliability and agreement. Sociological Methods \& Research, 42(3), 294-320.

[17] Cavendish, W. \& Hodnett, K. (2017). Collaborative Stratregic Reading. Retrieved from Current Practice Alerts website: https://s3.amazonaws.com/cmi-teaching-Id/alerts/35/uploaded_files/original_DLD_Alert26.pdf?1486204856

[18] Changwong, K., Sukkamart, A., \& Sisan, B. (2018). Critical thinking skill development: Analysis of a new learning management model for Thai high schools. Journal of International Studies Vol, 11(2), 11-2.

[19] Cheng, M. H. M., \& Wan, Z. H. (2017). Exploring the effects of classroom learning environment on critical thinking skills and disposition: A study of Hong Kong 12th graders in Liberal Studies. Thinking Skills and Creativity, 24, 152-163.

[20] Cline, F., Johnstone, C., \& King, T. (2006). Focus Group Reactions to Three Definitions of Reading (As Originally Developed in Support of NARAP Goal 1). National Accessible Reading Assessment Projects.

[21] Council of Europe. (n.d.). Our member states. Retrieved from https://www.coe.int/en/web/about-us/our-member-states

[22] Exam English. (n.d.). Job Adverts. Retrieved from https://www.examenglish.com/B2/b2_reading_people.htm

[23] Facione, P. A. (2016). Critical Thinking: What It Is and Why It Counts Peter A. Facione The. Molecular Imaging and Biology. https://doi.org/10.1007/s11307-016-1031-0

[24] Fahim, M., \& Sa'eepour, M. (2011). The impact of teaching critical thinking skills on reading comprehension of Iranian EFL learners. Journal of Language Teaching and Research, 2(4), 867.

[25] Grosas, A. B., Raju, S. R., Schuett, B. S., Chuck, J. A., \& Millar, T. J. (2016). Determining if active learning through a formative assessment process translates to better performance in summative assessment. Studies in Higher Education, 41(9), 1595-1611.

[26] Hafni, R. N. (2017). 21st Century Learner: Be A Critical Thinking. The Second of International Conference on Education and Regional Development 2017 (ICERD 2nd).

[27] Hove, G. (2011). Developing critical thinking skills in the high school English classroom (Doctoral dissertation, University of Wisconsin-Stout).

[28] Karimi, L., \& Veisi, F. (2016). The impact of teaching critical thinking skills on reading comprehension of Iranian intermediate EFL learners. Theory and Practice in Language Studies, 6(9), 1869-1876.

[29] Kasemsap, B., \& Lee, H. Y. H. (2015). L2 reading in Thailand: Vocational college students' application of reading strategies to their reading of English texts. The Reading Matrix: An International Online Journal, 15(2), 101-117.

[30] Khusniah, N. L. (2017). Improving English reading comprehension ability through survey, questions, read, record, recite, review strategy (SQ4R). English language teaching, 10(12), 202-211.

[31] Lynch, E. (2018). How To Teach Reading Comprehension Strategies In Your School? Retrieved from https://www.sadlier.com/school/elablog/how-to-use-and-teach-reading-comprehension-strategies-in-your-school

[32] Nugroho, A., Zamzami, M. R. A., \& Ukhrowiyah, N. F. (2020). Language input, learning environment, and motivation of a successful EFL learner. Journal on English as a Foreign Language (JEFL), 10(1), 46-69. 
[33] Ontario. Ministry of Education. (2005). Think Literacy: Cross-curricular Approaches, Grades 7-12: Subject-specific Examples. Core French, Grades 7-12. Retrieved from https://www.tcdsb.org/FORSTAFF/NewTeacherlnduction/Documents/crosscurric.pdf.

[34] Phakiti, A., \& Plonsky, L. (2018). Reconciling Beliefs about L2 Learning with SLA Theory and Research. RELC Journal, 49(2), $217-237$.

[35] Ploysangwal, W. (2018). An Assessment of Critical Thinking Skills of Thai Undergraduate Students in Private Thai Universities in Bangkok through an Analytical and Critical Reading Test. University of the Thai Chamber of Commerce Journal Humanities and Social Sciences, 38(3), 75-91.

[36] Silalahi, R. M. (2017). Assessing University Students' Critical Thinking Skill by Using the TOEFL ITP Reading Test. Lingua Cultura, 11(2), 7983.

[37] Suwantharathip, O. (2015). Implementing reading strategies based on collaborative learning approach in an English class. Reading Matrix: An International Online Journal, 15(1), 91-101.

[38] Thovuttikul, S., Ohmoto, Y., \& Nishida, T. (2019). Comparison of influence of Thai and Japanese cultures on reasoning in social communication using simulated crowds. Journal of Information and Telecommunication, 3(1), 115-134.

[39] Tung, C. A., \& Chang, S. Y. (2009). Developing critical thinking through literature reading. Feng Chia Journal of Humanities and Social Sciences, 19(3), 287-317.

[40] Tyson, K. (2014). 9 Definitions of Reading Comprehension. Retrieved from https://www.learningunlimitedllc.com/2014/05/9-definitionsreading-comprehension/

[41] Vaughn, S., Klingner, J. K., Swanson, E. A., Boardman, A. G., Roberts, G., Mohammed, S. S., \& Stillman-Spisak, S. J. (2011). Efficacy of collaborative strategic reading with middle school students. American educational research journal, 48(4), 938-964.

[42] Walker, S. E. (2003). Active learning strategies to promote critical thinking. Journal of athletic training, 38(3), 263.

[43] Wang, S., \& Seepho, S. (2017). Facilitating chinese efl learners' critical thinking skills: the contributions of teaching strategies. SAGE Open, 7(3), 2158244017734024.

[44] White, H., \& Sabarwal, S. (2014). Quasi-Experimental Design and Methods: Methodological Briefs-Impact Evaluation No. 8 (No. innpub753).

[45] Wilson, L. O. (2016). The second principle. Anderson and Krathwohl - Bloom's Taxonomy Revise. Retrieved from https://thesecondprinciple.com/wp-content/uploads/2019/10/blooms-taxonomy-revised.pdf.

[46] Winarso, W., \& Dewi, W. Y. (2017). Berpikir kritis siswa ditinjau dari gaya kognitif visualizer dan verbalizer dalam menyelesaikan masalah geometri. Beta: Jurnal Tadris Matematika, 10(2), 117-133.

[47] Yoosabai, Y. (2008). The Effects of Reciprocal Teaching on Thai High-School Students' English Reading Comprehension Ability. NIDA Development Journal, 48(4), 69-88.

[48] Zagoto, I. (2016). Collaborative strategic reading (CSR) for better reading comprehension. Komposisi: Jurnal Pendidikan Bahasa, Sastra, dan Seni, 17(1), 65-74.

[49] Zoghi, M., Mustapha, R., \& Maasum, T. N. R. B. T. M. (2010). Collaborative strategic reading with university EFL learners. Journal of College Reading and Learning, 41(1), 67-94. 